\title{
Kent - Yapı İlişkisi Bağlamında Araç Bomba Saldırılara Alınabilecek Önlemlerin AHP Yöntemi ile Değerlendirilmesi*
}

\author{
Berru İzel Gökgöz ${ }^{1}$ \\ ORCID: 0000-0002-0096-1595
}

*

\author{
Zeynep Yeşim İlerisoy² \\ ORCID: 0000-0003-1903-9119
}

Öz

Kent içinde meydana gelen saldirlarda, kentsel dokunun vazgeçilmez unsurlar olan yapılar ve yapıların çeoreleri ciddi zararlar almışlardır. Hasarn yayılmasını önlemek ve hasar alacak çeorenin en kısa sürede eski haline getirmek için, bomba riskini göz önüne alan tasarımlar gerçekleştirmelidir. Bu çalışmada yapılar üzerinde oluşan hasarın, patlamanın hangi tür özelliklerine bağgl olduğu belirlenmiştir. Daha sonra farkl ülkelerin standartlarn ve uzman görǚslerini de içeren literatür taraması ışı̆̆ında özellikle araç bomba saldırllarda kent ve yapı ilişkisi bağlaminda alnabilecek önlemler belirlenmiştir. Bu önlemler Çok Kriterli Karar Verme (ÇKKV) metodolojisinden Analitik Hiyerarşi Prosesi (AHP) yönteminden yararlanularak konunun uzmanları tarafindan değerlendirilmiştir. Değerlendirmeler sonucunda kent içindeki bu saldirlarda en önemli kriter Kamu Yollarna Mesafe, en az öneme sahip kriterin ise Diğer Riskli Yapılara Erişim kriteri olduğu sonucuna ulaşılmıştır. Kriter ağırlıkları bulunduktan sonra bu kriterler gözleme dayalı tespit yöntemi ile iki tren istasyonu numunesi üzerinde uygulanmıştır. Sonuç olarak, kent içindeki bombalı saldırılara karşı yapı ve çevresi kapsaminda öneriler sunan bu çalışma, bilinçli toplum ve güvenli kentleşmenin temellerinin atılmasına yönelik önem teşkil emektedir.

Anahtar Kelimeler: Araç Bomba Saldırılar, Kent İçi Bombalı Saldırılar, Analitik Hiyerarşi Prosesi (AHP), Çevre, Yapı Parseli

\footnotetext{
* Bu makale çalışması “5. Kent Araştırmaları Kongresi”nde bildiri olarak sunulmuştur.

1 Yüksek Lisans Öğrencisi, Gazi Üniversitesi, E-mail: berruizel@gmail.com

${ }^{2}$ Doç. Dr. Gazi Üniversitesi, E-mail: zyharmankaya@gazi.edu.tr

idealkent (c) Kent Araştırmaları Dergisi (Journal of Urban Studies) 


\title{
Evaluation of Measures in Urban Areas for Vehicle Bomb Attacks in The Context of City-Building Relation with AHP Method
}

\author{
Berru İzel Gökgöz 3 \\ ORCID: 0000-0002-0096-1595
}

\author{
Zeynep Yeşim İlerisoy 4 \\ ORCID: 0000-0003-1903-9119
}

\begin{abstract}
Buildings and their surroundings, which are indispensable elements of the urban fabric, are seriously damaged by the city's attacks. Designers should consider the bomb risk to prevent the spread of damage and restore the damaged environment as soon as possible. In this study, it was determined that the damage to the structures depended on the characteristics of the explosion. The measures taken in the interaction between the city and the building, especially in vehicle bomb assaults, were then decided based on the literature research, which included standards from other nations and expert opinions. The subject experts evaluated these measures using the Analytical Hierarchy Process (AHP) method from the Multi-Criteria Decision Making (MCDM) methodology. Thus, the evaluations, it was concluded that the most important criterion in these attacks in the city is Distance to Public Roads, and the least important criterion is Access to Other Risky Buildings. After the criterion weights were found, these criteria were applied on two train station samples by observation-based detection method. Finally, this study, which offers suggestions against the bomb attacks in the city within the scope of its structure and its environment, is important for laying the foundations of conscious society and safe urbanization.
\end{abstract}

Keywords: Vehicle-Borne Improvised Explosive Device Attacks, Urban Attacks, Analytical Hierarchy Process (AHP), Environment, Building Parcel

\footnotetext{
${ }^{3}$ Graduate Student. Gazi University, E-mail: berruizel@gmail.com

${ }^{4}$ Assoc. Prof. Dr. Gazi University, E-mail: zyharmankaya@gazi.edu.tr

idealkent (c) Kent Araştırmaları Dergisi (Journal of Urban Studies) 


\section{Giriş}

1980 sonrası dünyada artan küresel terörizm sebebiyle farklı ölçeklerde birçok bombalı saldırı yaşanmıştır. ${ }^{5}$ Bu saldırılar, başta meydana geldiği yapı ya da bölge olmak üzere tüm ülkeyi etkileyen insan kaynaklı afetlerdir. Bu saldırıların dönemsel olarak türleri ve yoğunluğu değişse de bu tür eylemler sonucu maddi ve manevi ciddi kayıplar yaşanmaktadır. Ülkemizde de pek çok patlayıcı esaslı saldırı yaşanmış, hala devam eden terör mücadelesi sebebiyle bombalı saldırı riski ortadan kalkmamıştır (Şekil 1).

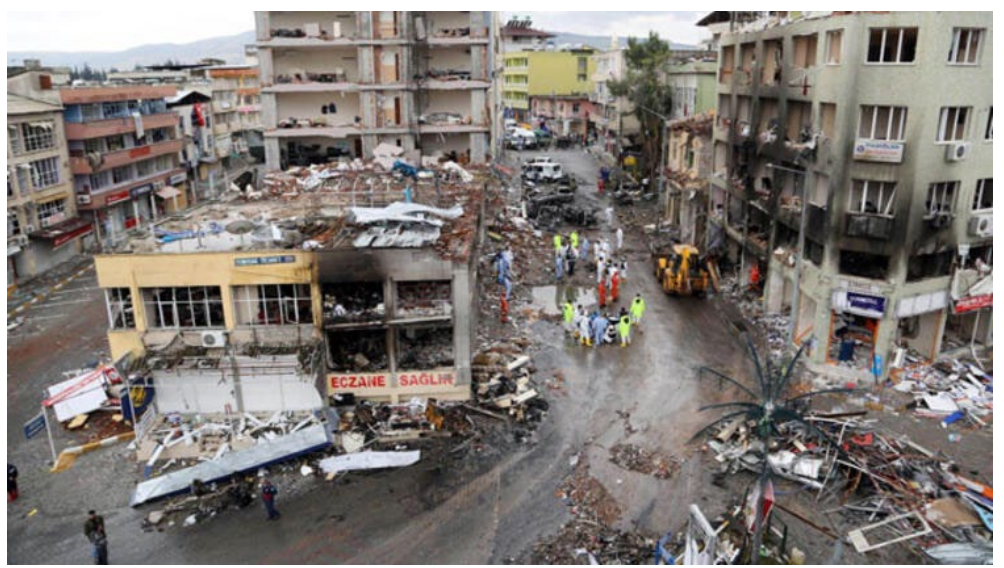

Şekil 1. Reyhanlı'da 11 Mayıs 2013 tarihinde gerçekleşen patlayıcı saldırı (Hürriyet, 2014)

Türkiye'nin son on yıllık yakın geçmişine bakıldığında kentsel alanlarda yaşanan acı saldırılardan 2011'de Ankara-Kumru sokak, 20 Temmuz 2015'te Suruç ve 15 Temmuz 2016'da Türkiye Büyük Millet Meclisi ilk akla gelenlerdir. Ek olarak, "tarihinin en büyük saldırısı" olarak basında yer alan 10 Ekim 2015 tarihindeki Ankara tren garı terör saldırısı ise kent içinde gerçekleştirilme ihtimali olan saldırılarda güvenlik açığını doğrulayan nitelikte acı bir örnektir (Şekil 2).

\footnotetext{
${ }^{5}$ Bu çalışma, Gazi Üniversitesi Fen Bilimleri Enstitüsü, Mimarlık Anabilim dalında Yüksek lisans tez programı çerçevesinde Doç. Dr. Zeynep Yeşim İlerisoy danışmanlığında sürdürülen Berru İzel Gökgöz'ün tez araştırmasının alan verilerine dayanmaktadır.
} 


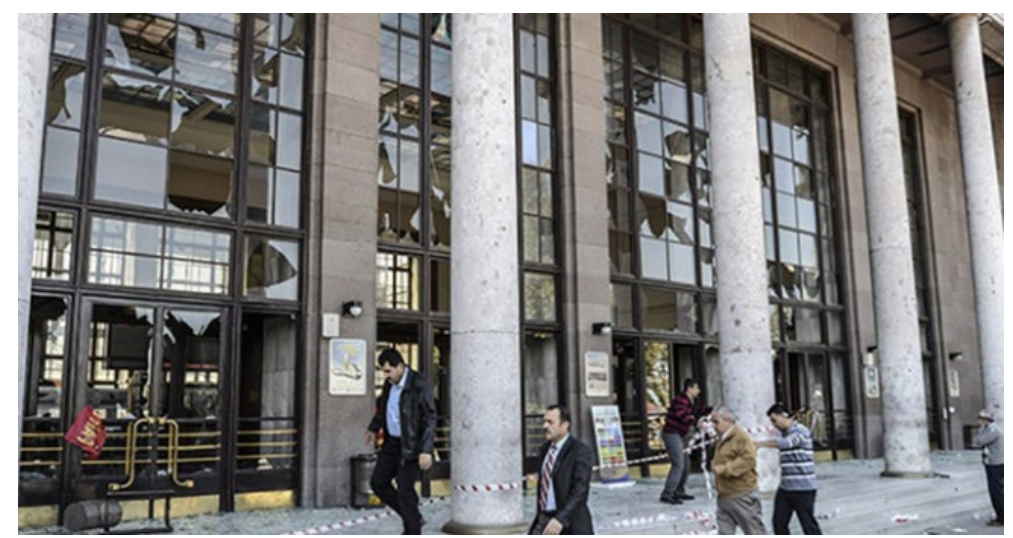

Şekil 2. Ankara Tren Garı'nda 10 Ekim 2015 tarihinde gerçekleşen patlayıcı saldırı (Yenimeram, 2015)

Uluslararası politikayı şekillendiren ve devletlerin güvenlik stratejilerini yeniden gözden geçirmesine sebep olan bu saldırılardan birçok ders çıkartılmış ve halen çıkartılmaktadır. Çıkartılan derslerden en önemlisi, meydana gelen bu bombalı saldırıların kesin olarak engellenemez olduğudur (Intelligence and Security Committee, 2006). Bu duruma en büyük sebep, bombalar için hammadde olarak kullanılan malzemelerin büyük çoğunluğunun çift kullanımlı malzeme olmasıdır. Yani üretim sanayisinde ve tarımda da kullanılmakta olup yasaklanma ihtimalleri yoktur (National Academies of Sciences, Engineering, and Medicine, 2018). Ek olarak, olay anında müdahale edilememesi de engellenememesinde önemli bir sebeptir.

Bombalı saldırıları gerçekleştiren teröristler, yasa dışı stratejik, sosyal ve politik amaçlarını gerçekleştirmek için kamuoyundaki güven duygusunu ortadan kaldırmak ve siyasal istikrarsızlık ortamı oluşturmak amacıyla bombalı saldırı girişimlerinde bulunmaktadır (Ergil, 1992, s. 140; Gençtürk, 2012, s. 5). Bu amaçlarına ulaşmak için saldırılara karşı savunmasız olarak görülen kent içindeki alanlar, yeterli güvenlik önlemlerinin olmadığı düşünülerek hedef olarak seçilmektedirler (Glaeser ve Shapiro, 2002). Bu tür, güvenlik önlemlerinin alınmasının zor olduğu savunmasız alanlar ve yapılar "yumuşak hedef" olarak adlandırılmaktadır. Yumuşak hedefler teröristler tarafından saldırılara bağlı can kaybını arttırmak için seçilmektedir (Karlos, Larcher ve Solomos, 2018). Bu hedeflerde ortaya ç1kan potansiyel hasar ve yaşananlar çok boyutlu olmaktadır. Sonrasındaki iyileştirmeler de ileri derecede maliyetli ve zaman gerektiricidir. 
Bombalı saldırıların direkt maliyetler dışında bedeli ölçülemeyecek çok ciddi kayıplara sebep olmaları, olası tehditlerin önüne geçmek ve can güvenliğini sağlamak ihtiyacını doğurmaktadır. Bu doğrultuda da yapı ve kent ölçeğinde bombalı saldırılara yönelik gereken önlemleri alınması gündeme gelmektedir. Ancak, önlemlerin alınması için öncelikle bu sald1rıların çevresini nasıl etkilediğini bilinmelidir.

Bombalı saldırılar, çevresindeki bireyleri, yapıları ve diğer nesneleri patlama basınc1, darbe hasarı ve isı yoluyla etkilemektedir. Patlama basınc1, infilak sonrasında oluşan kuvvettir, darbe hasarı ise patlamanın ikincil etkisi olarak cam, beton, tuğla gibi parçacıkların sesten çok daha yüksek bir hızla etrafa saçılmasıdır. Bunların yanı sıra yüksek ısı patlama kaynağı ve yakın çevrenin yanmasına sebep olmaktadır. Patlamanın yapılar üzerindeki hasar boyutları da farklı değişkenlere bağlıdır (FEMA 427, 2003a; Kang ve Lee, 2014; Kang, Park, Heo, Lee ve Lee, 2019). Bu etkileri sıralamak gerekirse (Şekil 3);

- Patlamanin yeri,

- Patlayıcı maddenin türü ve miktarı (ağırlığı),

- Patlama merkezi ile yapı arasındaki mesafe,

- Etkilenecek yapıların özellikleridir.

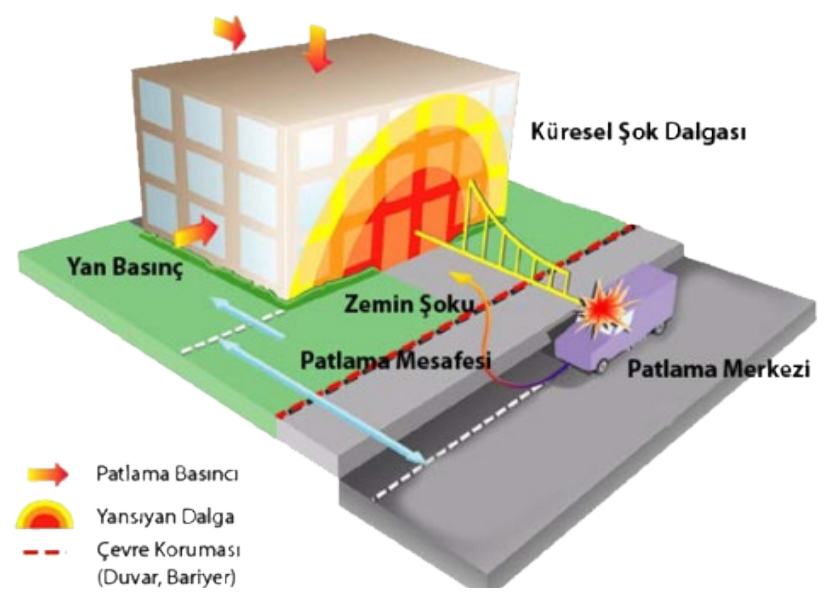

Şekil 3. Tehdit parametreleri ve tanımları (FEMA 427, 2003a)

Patlamanın yeri ile patlayıcı maddenin türü ve miktarı kestirilememektedir. Yalnızca, patlamanın merkezi ile yapı arasındaki mesafe ile etkilenecek yapıların özelliklerine müdahale edilerek hasarlar azaltılabilir. Patlamanın verdiği hasarlar ve hasarları etkileyen sebepler düşünüldüğünde, 
mimari tasarım ile güçlendirilen yapı ve çevresi kapsamında alınacak önlemler bombalı saldırılarla başa çıkabilme yeteneğinde önem teşkil etmektedir. Alınacak önlemler kapsamında ise kentsel yapılaşma, mimari tasarım, yapı parseli, bina biçimlenmesi ve tüm bu aşamalardaki tasarım kararlarını etkileyen pek çok kriter bulunmaktadır. Benzer şekilde ele alınan bombalı saldırıların kişi intihar saldırıları, paket bomba saldırıları, araç bomba saldırıları gibi çeşitliliği de alınacak önlemlerde önemli bir değişken olmaktadır. Bu çalışmada söz konusu kriterlerin doğru ve sistematik bir şekilde değerlendirilebilmesi için sınırlıklar getirilmiştir. Öncelikle çalışmada kentlerde gerçekleştirilen saldırılar içerisinde en fazla başvurulan araç bomba saldırılara karşı tasarım sürecinde alınabilecek önlemler ele alınmıştır. Bu noktada ise yapı ve çevresi kapsamında tasarım kararlarının, kentlerde bombalı saldırılara karşı korunma sürecindeki etkileri ortaya koyularak; binalar özelindeki biçimlenme, mimari tasarım ve malzemem kararları kapsam dışında tutulmuştur. Belirlenen sınırlar doğrultusunda tasarım kriterlerini elde etmek için ise öncelikle kapsamlı bir literatür taraması yapılmıştır.

Bombalı saldırılara karşı tasarıma ilişkin literatür incelendiğinde patlama etkileri ve alınabilecek mimari tasarım önlemleri için çeşitli önerilerde bulunulduğu görülmüştür (Coaffee, Moore, Fletcher ve Bosher, 2008; Eskew ve Jang, 2012; Gebbeken ve Döge, 2010; Kang ve Lee, 2014; Smilowitz, 2016). Bu çalışmalara kısaca değinmek gerekirse, Kang ve Lee yapmış oldukları çalışmada, son yıllarda kamu binalarının güvenliğine daha fazla önem verilmesi ile otel, alışveriş merkezleri, metro istasyonları gibi yapılar teröristler için potansiyel olarak daha yumuşak hedef haline geldiği belirtilmiştir. Yüksek yapılara yönelik saldırıların önlenmesi ve azaltılmasında savunma unsurlarının göreceli önemi Analitik Hiyerarşi Prosesi anketi ile belirlenmiştir. Tasarım unsurlarının ağırlıklarına dayanarak koruma seviyesini ve ek etkileri dikkate alan güvenlik açı̆̆ değerlendirme modeli geliştirilmiş ve uygulanabilirliği test edilmiştir (Kang ve Lee, 2014). Eskew ve Jang'ın yapmış oldukları çalışmada, geçmişte yaşanmış terörist saldırı örnekleri üzerinden patlama etkileri ve potansiyel etkilerini en aza indirmek için patlamaların temel ilkeleri araştırılmıştır. Bu araştırmaların sonucunda hasarlı bir yapı için analiz teknikleri ile bu teknikleri doğrulamak ve kanıtlamak için kullanılan deneysel yöntemler derinlemesine araştırılmıştır (Eskew ve Jang, 2012). Smilowitz'in yapmış olduğu çalışmada, saldırılarda acil durum hizmetlerinin korunması gibi hu- 
suslarda temel tasarım hedefleri arasında sunulmuştur. Tasarım hedeflerinin oluşturulmasından önce patlamanın çevresini nasıl etkilediği üzerinde durulmuştur. Bunlara ek olarak yapı tasarımında alınmış sismik önlemlerin patlama etkilerine karşı da koruma sağlayabileceği belirtilmiştir (Smilowitz, 2016). Coaffee ve arkadaşlarının yapmış oldukları çalışmada ise, saldırılara karşı savunmasız görülen kalabalık alanların tasarımı üzerinde durulmuştur. Saldırı tehditlerinin oluşumunu veya etkisini azaltabilecek şekilde yapı tasarlamak için uzman mimar ve mühendislerinde dahil olduğu bir tasarım sürecinin gerekliliğini belirtmişlerdir (Coaffee ve diğerleri, 2008). Gebbeken ve Döge'nin yapmış oldukları çalışmada, patlama dalgası yayılımı ve yansıması hakkında bilgi verilmektedir. Yapılan çalışmaya göre patlama dalgası yayılımı ve yansıması yapının şekli ve boyutuna göre farklılık göstermektedir. Patlama etkilerinin azaltılması konusunda peyzaj modellemesi ile patlayıcı etkilerini sönümleyici malzemelerin yapılarda kullanılmasının etkili olduğu sonucuna ulaşılmıştır (Gebbeken ve Döge, 2010).

Bu çalışmalara ek olarak farklı ülkelerin bombalı saldırılara yönelik geliştirmiş oldukları çalışmalar bulunmaktadır. İngiltere tarafından birçok standart geliştirilmiş olup, çoklu yayınlanan bu standartlar; teknik bilgiler içermemekte, kalabalık mekanlar, oteller, alışveriş merkezleri, iş merkezleri için alınması gereken güvenlik önlemlerine yönelik teorik tasarım önerileri verilmektedir (NaCTSO, 2006, 2008a, 2008b, 2012, 2014). Amerika'da 11 Eylül Saldırısı ile patlayıcı saldırılara yönelik önemli dersler alınmıştır. Bu anlamda birçok kılavuz ve standart geliştirilmiştir (FEMA 426, 2003a; FEMA 427, 2003b; FEMA 428, 2003c; FEMA 452, 2005; FEMA 430, 2007; FEMA 426 BIPS 06, 2011; General Services Administration (GSA), 2013; US Department of Defense, 2005, 2007). Çoklu yayınlanan bu standartlarda dinamik tasarım kriterlerini, yapısal analizleri ve hesaplamaları verilmektedir. Ayrıca farklı yapı türlerini ve kentlerin korunmasını kapsayan, mimari yaklaşımlara yönelik bölümler de bulunmaktadır. Singapur hükümeti, günümüzde artan terör saldırısı tehdidi karşısında yap1 güvenliği uygulamaları ve risk değerlendirmelerinin nasıl yürütüleceğine ilişkin kapsamlı bir kılavuz hazırlamıştır (Singapore Ministry of Home Affair, 2018). Bu kılavuz, teknik bilgiler içermezken, patlama tehditlerini ve yoğun kullanıcılı bina ve alanlarda alınabilecek önlemler verilmiştir. Hindistan hükümeti tarafından ise, 1968 yılında bir standart geliştirilmiştir (Bureau of Indian Standards [BIS], 1969). Bu standart, patlamalar için pat- 
layıcı yapı tasarımı için statik tasarım kriterlerini içermektedir. Statik tasarıma yönelik, patlama yükleri, etkileri ve hesaplamalarını içermektedir. Son olarak Türkiye'de ise Emniyet Genel Müdürlüğü (EGM) tarafından "Emniyet Yapıları" na yapılan saldırıların artışı neticesinde bu yapılara yönelik bir kılavuz hazırlanmıştır (EGM, 2019). Bu kılavuz, EGM'nin yapmış olduğu istatistikler ile Türkiye'de patlama risk bölgeleri haritasını oluşturmuştur (Şekil 4). Harita, illere göre olası patlama esaslı saldırı ihtimalleri için bir kaynak teşkil etmektedir. Türkiye'deki genel dağılımı yorumlamak gerekirse, riskin batıya doğru azalmasına karşın, özellikle büyük kentler, stratejik önemleri sebebiyle bir üst kademede risk taşımaktadır.

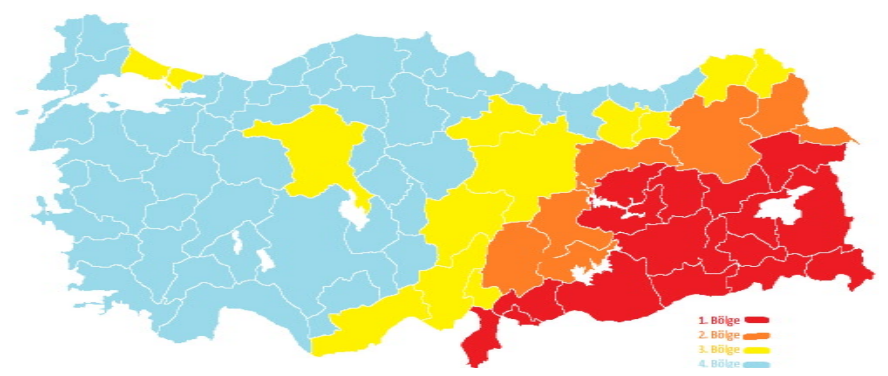

Şekil 4. Patlama Risk Bölgeleri Haritası (EGM, 2019)

Yukarıda bahsedilen literatür taraması ışığında, kent içindeki araç bomba saldırılarına karşı alınacak önlemlere ilişkin tasarımsal kriterlerin belirlenmesinde "Çok Kriterli Karar Verme" (ÇKKV) metodolojisinden Analitik Hiyerarşi Prosesi (AHP) yöntemine başvurulmuştur. Bunun nedeni, kentlerde bombalı saldırılara yönelik çeşitli ve birlikte değerlendirilmesi gereken çok sayıda tasarım kriterinden oluşuyor olmasıdır. Bu kriterler literatür taraması ve uzman görüşleri neticesinde belirlenmiştir. Süreçteki etkilerinin yanında mertebelerine yönelik tasarım kriterleri arasında hiyerarşik bir sıralama elde edilmiştir.

\section{Yöntem}

Çalışmanın amacı, yapıların kent içi bomba saldırılara karşı korunma seviyelerini çevresel tasarım kararları ile karşılaştırma imkânı veren hiyerarşik yapıda bir değerlendirme yöntemi geliştirmektir. Çalışmanın ilk bölümünde literatür taraması ve uzman görüşleri ile belirlenmiş patlayıcı saldırılara karşı kentsel tasarıma ilişkin kriterlere yer verilmiştir. Bu kriterler farklı tecrübe, bilgi, eğitim sahibi bireylerin çalışmasını birleştirerek 
ortak bir bulguya ulaştıran Çok Kriterli Karar Verme (ÇKKV) metodolojisinden Analitik Hiyerarşi Prosesi (AHP) yöntemi kullanılarak değerlendirilmiştir. AHP yöntemi, Thomas L. Saaty tarafından bu tür karmaşık çok kriterli karar verme problemlerinde kriterler arasında öncelikleri ve ardından alternatif çözümler elde etmek için birçok yargıyı sentezlemek için kullanılan prosedürleri ve ilkeleri içeren, problemlerle başa çımak için tasarlanmıştır (Saaty ve Kearns, 1985, s.19). Bu yöntem temel birkaç adımdan oluşmaktadır. Bu adımlar (Gökgöz, İlerisoy ve Soyluk, 2020):

- Karar verme probleminin tanımlanması ve karar problemin hiyerarşik yapısının oluşturulması

- İkili karşılaştırma matrisi kullanılarak kriter ağırlıklarının belirlenmesi

- Kriterlere göre alternatiflerin ikili karşılaştırılması ve önceliklerinin hesaplanması

- Kriter karşılaş̧ırmaları için tutarlılık oranı hesaplanması

Hiyerarşik yapının oluşturulmasında öncelikle karar probleminin tanımlanması gerekmektedir. Bu çalışmada kentsel alanlarda araç bomba saldırılara karşı çevresel tasarımı karar problemidir. Bu probleme ilişkin kriterler arasında ikili karşılaştırmalar oluşturulur. Bu karşılaştırmalarda Saaty'nin 1-9 ölçeği kullanılır.

Tablo 1. AHP Önem Dereceleri

\begin{tabular}{ll}
\hline Önem Derecesi & Tanım \\
\hline 1 & Eşit derecede önemli \\
\hline 3 & Orta derece önemli \\
\hline 5 & Kuvvetli derecede önemli \\
\hline 7 & Çok kuvvetli derecede önemli \\
\hline 9 & Mutlak derecede önemli \\
\hline $2,4,6,8$ & Ara değerler \\
\hline
\end{tabular}

İkili karşılaştırmaların uzmanlar tarafından yapılıp, kriterler önceliklerinin hesaplanmasının ardından, ikili karşılaştırmalar uzmanların sübjektif değerlendirmelerine dayandığı için oluşabilecek tutarsızlıklar değerlendirilir. Tutarsızlıkların tespiti halinde ikili karşılaştırma adımı tekrarlanır.

Çalışmanın ikinci bölümünde, gözleme dayalı tespit yöntemi kullanılmıştır. Gözleme dayalı tespit yöntemi, mevcut belge araştırmaları ve yapının mevcut durumuna ilişkin incelemeleri kapsar. Yapının karşı karşıya kaldığı risklerin tespiti için çalışma bölümlere ayrılmış ve bölümler arasında sistema- 
tik bir ilişki kurularak, yapıların bir bütün olarak değerlendirmesi gerçekleştirilmiştir. Alan çalışmasında veri elde edilme yöntemlerinin sıralı yapılması doğru verilere ulaşmak ve analizlerin tamamlanması için önem arz etmektedir. Bu çalışma ile kent ölçeğinde önem teşkil eden ulaştırma yapılarından yüksek hızlı tren garı yapılarının araç bomba saldırılara karşı güvenlik düzeylerine göre bir karşılaştırılma yapılacaktır. Yüksek hızlı tren garları, diğer ulaşım yapılarının aksine kent içinde bulunan, günün her saati kullanılan yoğun alanlar oldukları için; bu tür saldırılar, yapılar ve yapı çevresinin korunumu için bir endişe kaynağıdır. Bu nedenle yapı çevresinin kent içerisindeki tasarımı son derece önemli olmakta, güvenlik düzeylerinin arttırılması kentleşme stratejilerinde hayati değer taşımaktadır.

Çalışmada oluşturulan karşılaştırma yönteminin aynı fonksiyona sahip yapılarda uygulanması, güvenlik düzeyini etkileyen mevcut durum ve tasarım kararlarını ortaya çıkarmakta, ayrıntılı tespite ihtiyaç duyulan noktaları belirlemektedir. Sonuç olarak, çalışmada yapıların güvenlik durumunun değerlendirilmesine ilişkin bir ön değerlendirme yapılmaktadır.

\section{Değerlendirme Kriterleri}

Kent içindeki araç bombalı saldırılara karşı çevresel tasarıma yönelik, uzman görüşleri ve literatür taraması ile iki koruma katmanı ana başlık olarak oluşturulmuştur. Bu koruma katmanlarına bağlı tasarım elemanları da alt parametreler olarak belirlenmiş ve değerlendirmeleri yapılmıştır (Tablo 2).

Tablo 2. Ana Kriterler ve Alt Parametreler

\begin{tabular}{|c|c|c|}
\hline Koruma Katmanı & İlave Grup & Tasarım Elemanı \\
\hline \multirow[t]{3}{*}{ Ç. Çevre ile İlişki } & & Ç.1. Kent İçindeki Konumu \\
\hline & & Ç.2. Kamu Yollarına Mesafe \\
\hline & & Ç.3. Arsa Çeperindeki Araç Parkları \\
\hline \multirow{6}{*}{$\begin{array}{l}\text { P. Yapı Parselinin } \\
\text { Düzenlemesi }\end{array}$} & \multirow[t]{3}{*}{ P.A. Parsel Güvenliği } & P.1. Çevre Güvenlik Duvarı \\
\hline & & P.2. Araç Kontrol Noktaları \\
\hline & & P.3. Parsel İçi Güvenlik Önlemleri \\
\hline & \multirow{3}{*}{ P.B. Parsel-Bina İlişkisi } & P.4. Bina Yerleşim/Yönlenme \\
\hline & & P.5. Açık Otopark Konumu \\
\hline & & P.6. Diğer Riskli Yapılara Erişim \\
\hline
\end{tabular}




\section{Ç. Çevre ile İlişki}

Çevre ile ilişki, yapı adası dışında kontrolü zor olan hatta kontrol edilemeyen alanları (yolları, kaldırımı, komşu parselleri, komşu yapı adalarını) kapsamaktadır. Bu başlıkta alınacak önlemler çevrenin, yapı parseli üzerindeki riskleri azaltılarak hedef yapının korunması arttırmaktadır. Örneğin, "kent içinde konumu" na bağlı olarak, bölgede yüksek yoğunluklu alanlardaki hedefler güvenlik uzmanları için yumuşak hedef olarak değerlendirilmektedir. Yapının "kamu yollarına mesafe" sinin arttırılması patlama etkilerini büyük ölçüde azaltarak yapının etkilenme ihtimalini düşürür. Kent merkezlerinde bu parametreyi kontrol etmek oldukça zordur. Ancak yapıları değerlendirirken önem teşkil eder. "Arsa çeperindeki araç parkları" ise, araç bomba saldırıları ile teröristlere büyük miktarlarda patlayıcıyı hedefe yaklaştırma fırsatı sunmaktadır (Lew, 2012). Bu nedenle potansiyel risk taşıyan bir uygulama olup, park yasağı getirilmesi ve tasarım kararları ile araçların kontrolsüz bir şekilde konumlanmasının önüne geçecektir.

\section{P. Yapı Parselinin Düzenlenmesi}

Arsa sınır ile bina arasındaki alanın iyi tasarlanmış olması, zayıf noktaları azaltarak hedef seçilme ihtimalini düşürür, planlanacak eylemin tespitini kolaylaştırır ve caydırıcı bir kalkan olur. "Parselin Güvenliği," kent ile olan ilişki ve kontrollü erişimi; "Binanın Parsel ile İlişkisi”" de binanın etkilenme sürecindeki vaziyet planı kararlarını ifade etmektedir. Bu bağlamda belirtilen alt gruplara ait tasarım elemanları da bulunmaktadır. Parsel güvenliği kapsamında, "Çevre Güvenlik Duvarı", "Araç Kontrol Noktaları" ve "Parsel içi Güvenlik Önlemleri" tasarım elemanları ele alınmıştır. Binanın parsel ile ilişkisi kapsamında ise, "Bina Yerleşimi/Yönlenmesi", "Araç Kontrol Noktaları" ve "Parsel içi Güvenlik Önlemleri" tasarım elemanları ele alınmıştır.

\section{Alan Çalışması}

Çalışma kapsamında geliştirilen karşılaştırma metodu ile, kentlerin gelişmesinde ve kentsel mekânların oluşumunda önemli olan, yoğun kullanıcısı bulunan tren garları değerlendirilmek istenmiştir. Yüksek hızlı tren garları, ülkemizde 2009 yılında yüksek hızlı tren kullanımının başlaması ile artan yolcu sayısını karşılamak ve yolcuları çeşitli sosyal donatılarla bir araya getirmek için tasarlanmış yeni nesil tren garlarıdır. Genişleyen ağ 
yapısı nedeniyle sayısı artmakta olan tren garları, günümüz modern mimarlık anlayışının önemli örnekleri arasında yer almaktadır. Yapılan çalışmada ülkemizin iki büyükşehrinde bulunan yüksek hızlı tren garı seçilerek çevresindeki patlayıcı saldırı riskleri tespit edilmeye çalışılmıştır. Seçilen tren garları, güvenlik hassasiyeti nedeniyle çalışmanın bütününde $\mathrm{A}$ Tren Garı ve B Tren Garı şeklinde adlandırılmıştır. Ana arter üzerindeki A Tren Garı, kentsel doku içerisinde merkezi bir konuma sahiptir. B Tren Garı'nın ise konumlandığı alan ve çevresi kentsel dönüşüm alanıdır.

Araştırmada ilk aşama için belirlenmiş olan kente dair tasarım kriterleri dikkate alınarak, yüksek hılı tren garları tasarımlarının bu kriterlere göre performansları karşılaştırılmış; gar tasarımları arasındaki ilişki araştırılmıştır. Bu araştırma sonucu elde edilen veriler ışığında yüksek hızlı tren garları ve çevresi için alınan olumsuz kararlar, yapılan hatalı uygulamalar ve sorunları tespit edilmiş, mevcudu iyileştirmeye ve yeni yapılacak uygulamalara yönelik değerlendirmeler yapılmış ve öneriler sunulmuştur.

\section{Koruma Katmanları ve Tasarım Elemanlarının Öncelik Dereceleri}

Yöntemin ikinci aşamasında, konuya yönelik önceden bilgi ve deneyime sahip olan öğretim üyelerinin yer aldığı uzmanlar grubu tarafından Saaty'nin 1-9 ölçeği (Tablo 1) kullanılarak kente dair tasarım kriterleri ve alt parametreleri için ikili karşılaştırma matrisleri oluşturulmuştur. Karşılaştırılan kriterlerin ve alt parametrelerin önem derecelerini vermek için karşılaştırma matrisleri normalize edilmekte ve değerlendirmelerde herhangi bir tutarsızlık olup olmadığının test edilmektedir. Yapılan bu çalışmada, uzmanlar grubunun yanıtlarının tutarlılık oranları 0,1'den küçük olduğu kabulü ile yapılmıştır. Buna göre ana kriterler ve alt parametrelere ilişkin öncelikli vektörel değerlendirmeler Tablo 3 ile Tablo 7 arasında verilmiş ve yorumlanmiştır.

Tablo 3. Koruma Katmanlarına İlişkin Öncelikli Vektör Hesabı

\begin{tabular}{llll}
\hline Koruma Katmanları & $\begin{array}{l}\text { Ç. Çevre ile } \\
\text { İlişki }\end{array}$ & $\begin{array}{l}\text { P. Yapı Parselinin } \\
\text { Düzenlemesi }\end{array}$ & Ortalama \\
\hline Ç. Çevre ile İlişki & 0,177 & 0,173 & 0,175 \\
\hline P. Yapı Parselinin Düzenlemesi & 0,823 & 0,827 & 0,825 \\
\hline Toplam & $\mathbf{1 , 0 0 0}$ & $\mathbf{1 , 0 0 0}$ & $\mathbf{1 , 0 0 0}$ \\
\hline
\end{tabular}


Tablo 3'te en sağda, kriterlerin öncelikler vektörü önemlerini gösteren ortalama değerleri sütunu incelendiğinde Yapı Parselinin Düzenlemesi koruma katmanı 0,825 değeri ile en yüksek öneme sahip olduğu ve Çevre ile İlişki koruma katmanının 0,175 değeri ile izlemektedir.

Tablo 4. Çevre ile İlişki Koruma Katmanı Tasarım Elemanlarına İlişkin Öncelikli Vektör Hesabı

\begin{tabular}{lrccc}
\hline Tasarım Elemanı & $\begin{array}{c}\text { Ç.1.Kent } \\
\text { Iç̧indeki } \\
\text { Konumu }\end{array}$ & $\begin{array}{c}\text { Ç.2 Kamu } \\
\text { Yollarına } \\
\text { Mesafe }\end{array}$ & $\begin{array}{c}\text { Ç.3.Arsa } \\
\text { Çeperindeki } \\
\text { Araç Parkları }\end{array}$ & Ortalama \\
\hline Ç.1.Kent İçindeki Konumu & 0,249 & 0,256 & 0,223 & 0,242 \\
\hline Ç.2.Kamu Yollarına Mesafe & 0,591 & 0,607 & 0,634 & 0,611 \\
\hline $\begin{array}{l}\text { Ç.3.Arsa Çeperindeki Araç } \\
\text { Parkları }\end{array}$ & 0,160 & 0,137 & 0,143 & 0,147 \\
\hline Toplam & $\mathbf{1 , 0 0 0}$ & $\mathbf{1 , 0 0 0}$ & $\mathbf{1 , 0 0 0}$ & $\mathbf{1 , 0 0 0}$ \\
\hline
\end{tabular}

Tablo 4'de en sağda, kriterlerin öncelikler vektörü önemlerini gösteren ortalama değerleri sütunu incelendiğinde Kamu Yollarına Mesafe tasarım elemanı 0,611 değeri ile en yüksek öneme sahip olduğu ve Arsa Çeperindeki Araç Parkları tasarım elemanı 0,147 değeri ile izlemektedir.

Tablo 5. Yapı Parselinin Düzenlemesi Koruma Katmanı Tasarım Elemanlarına İlişkin Öncelikli Vektör Hesabı

\begin{tabular}{llll}
\hline Tasarım Elemanı & $\begin{array}{l}\text { P.A. Parsel } \\
\text { Güvenliği }\end{array}$ & $\begin{array}{l}\text { P.B. Parsel-Bina } \\
\text { Illişkisi }\end{array}$ & Ortalama \\
\hline P.A. Parsel Güvenliği & 0,530 & 0,530 & 0,530 \\
\hline P.B. Parsel-Bina İlişkisi & 0,470 & 0,470 & 0,470 \\
\hline Toplam & $\mathbf{1 , 0 0 0}$ & $\mathbf{1 , 0 0 0}$ & $\mathbf{1 , 0 0 0}$ \\
\hline
\end{tabular}

Tablo 5'te en sağda, kriterlerin öncelikler vektörü önemlerini gösteren ortalama değerleri sütunu incelendiğinde Parsel Güvenliği tasarım elemanı 0,530 değeri ile en yüksek öneme sahip olduğu ve Parsel-Bina İlişkisi tasarım elemanı 0,470 değeri ile izlemektedir.

Tablo 6. Parsel Güvenliği Tasarım Elemanlarına İlişkin Öncelikli Vektör Hesabı

\begin{tabular}{lllll}
\hline Tasarım Elemanı & $\begin{array}{c}\text { P.1. Çevre } \\
\text { Güvenlik } \\
\text { Duvarı }\end{array}$ & $\begin{array}{c}\text { P.2. Araç } \\
\text { Kontrol } \\
\text { Noktaları }\end{array}$ & $\begin{array}{c}\text { P.3. Parsel İçi } \\
\text { Güvenlik } \\
\text { Önlemleri }\end{array}$ & Ortalama \\
\hline P.1. Çevre Güvenlik Duvarı & 0,451 & 0,414 & 0,519 & 0,461 \\
\hline P.2. Araç Kontrol Noktaları & 0,380 & 0,350 & 0,287 & 0,339 \\
\hline $\begin{array}{l}\text { P.3. Parsel İçi Güvenlik } \\
\text { Önlemleri }\end{array}$ & 0,169 & 0,236 & 0,194 & 0,200 \\
\hline Toplam & $\mathbf{1 , 0 0 0}$ & $\mathbf{1 , 0 0 0}$ & $\mathbf{1 , 0 0 0}$ & $\mathbf{1 , 0 0 0}$ \\
\hline
\end{tabular}


Tablo 6'da en sağda, kriterlerin öncelikler vektörü önemlerini gösteren ortalama değerleri sütunu incelendiğinde Çevre Güvenlik Duvarı tasarım elemanı 0,461 değeri ile en yüksek öneme sahip olduğu ve Parsel İçi Güvenlik Önlemleri tasarım elemanı 0,200 değeri ile izlemektedir.

Tablo 7. Parsel-Bina İlişkisi Tasarım Elemanlarına İlişkin Öncelikli Vektör Hesabı

\begin{tabular}{lcccc}
\hline Tasarım Elemanı & $\begin{array}{l}\text { P.4. Bina } \\
\text { Yerleşim / } \\
\text { Yönlenme }\end{array}$ & $\begin{array}{l}\text { P.5. Açık } \\
\text { Otopark } \\
\text { Konumu }\end{array}$ & $\begin{array}{l}\text { P.6. Diğer Riskli } \\
\text { Yapılara Erişim }\end{array}$ & Ortalama \\
\hline $\begin{array}{l}\text { P.4. Bina } \\
\text { Yerleşim/Yönlenme }\end{array}$ & 0,488 & 0,471 & 0,514 & 0,491 \\
\hline $\begin{array}{l}\text { P.5. Açı Otopark } \\
\text { Konumu }\end{array}$ & 0,320 & 0,308 & 0,284 & 0,304 \\
\hline $\begin{array}{l}\text { P.6. Diğer Riskli } \\
\text { Yapılara Erişim }\end{array}$ & 0,192 & 0,221 & 0,202 & 0,205 \\
\hline Toplam & $\mathbf{1 , 0 0 0}$ & $\mathbf{1 , 0 0 0}$ & $\mathbf{1 , 0 0 0}$ & $\mathbf{1 , 0 0 0}$ \\
\hline
\end{tabular}

Tablo 7'de en sağda, kriterlerin öncelikler vektörü önemlerini gösteren ortalama değerleri sütunu incelendiğinde Bina Yerleşim/Yönlenme tasarım elemanı 0,491 değeri ile en yüksek öneme sahip olduğu ve Diğer Riskli Yapılara Erişim tasarım elemanı 0,205 değeri ile izlemektedir. Bu adımların ardından da koruma katmanları ve tasarım elemanlarına ilişkin global ağırlıklar hesaplanmıştır (Şekil 5).

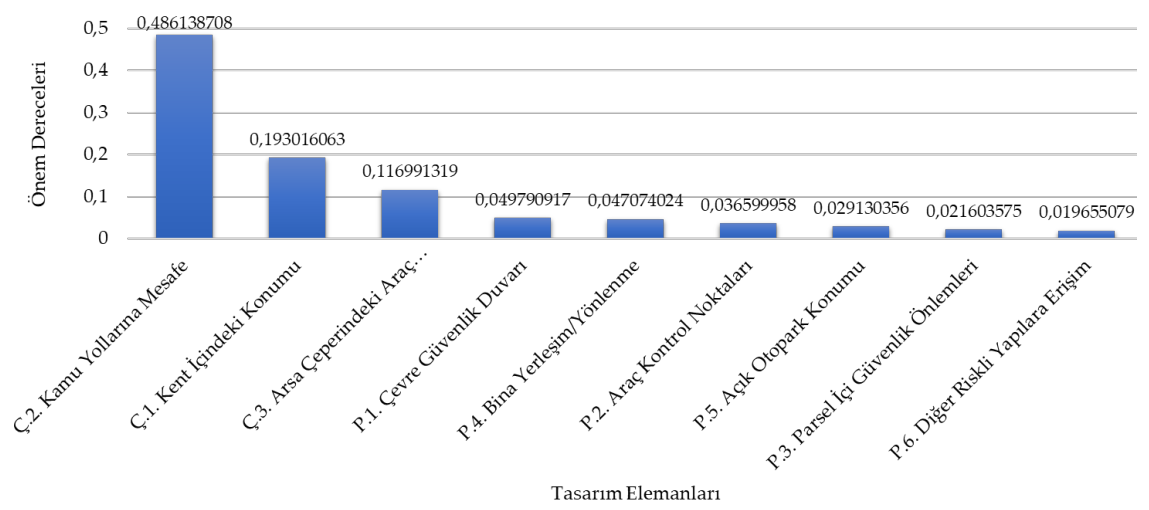

Şekil 5. Tasarım Elemanlarına İlişkin Global Ağırlıklar

Yapılan karşılaştırmalara göre Kamu Yollarına Mesafe tasarım elemanı en yüksek ağırlığa $(0,486)$ sahip olduğu, Diğer Riskli Yapılara Erişim tasarım elemanının ise en düşük ağırlığa $(0,019)$ sahip olduğu tespit edilmiştir. 


\section{Seçilen Yüksek Hızlı Tren Garlarının Değerlendirmesi}

Tren garlarının kent içindeki bombalı saldırılara karşı performanslarının değerlendirilmesinde belirlenen kriterlere beşli dereceleme sistemi uygulanmıştır. Bombalı saldırılara karşı riskin en az olduğu durum 5 ile derecelendirilirken, riskin en fazla olduğu durum 1 olarak derecelendirilmiştir. Bu derecelendirmeye göre tasarım elemanlarının A-Tren Garı ve B Tren Garı özelindeki değerlendirmeleri Şekil 6’da gösterilmiştir.

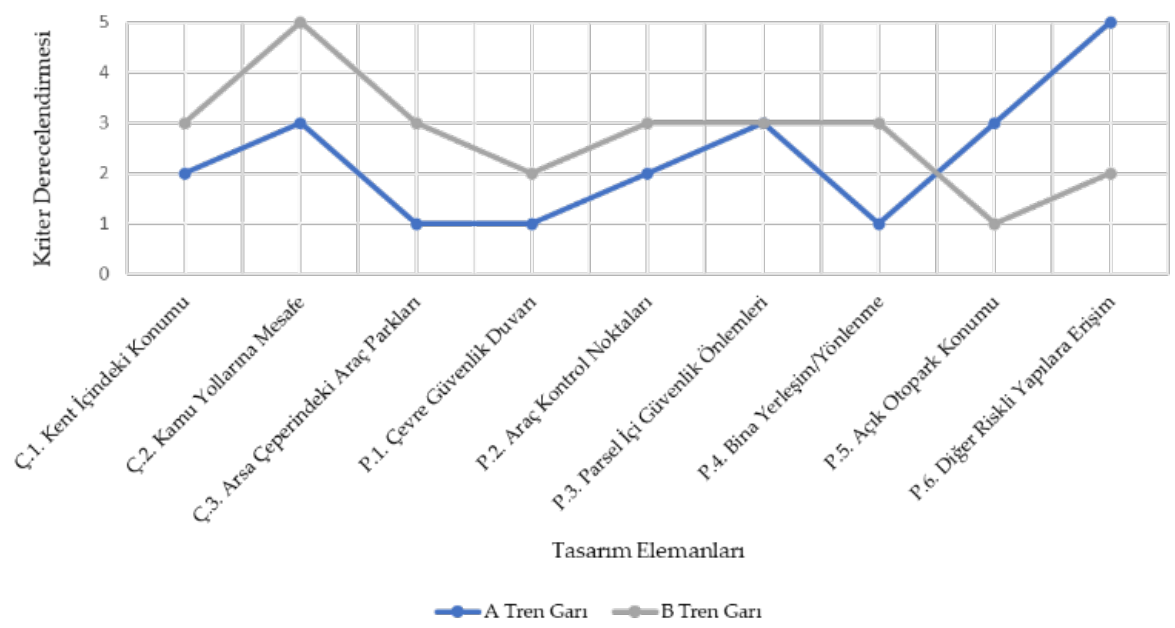

Şekil 6. Tren Garları Tasarım Elemanları Derecelendirmesi

\section{Kent İçindeki Konumu}

Yapıların kent içindeki konumları, bölgedeki bina popülasyonuna yönelik kentsel doluluğun bir göstergesidir. Yapılan araştırmalar yoğunluğun fazla olduğu alanların daha fazla suç oranına sahip olduğunu göstermektedir (Booth, Welch ve Johnson, 1976; NaCTSO, 2014). Bu yoğunluk, bu alanları bombalı saldırılara karşı hedef haline getirmektedir. Güvenlik endeksli tasarım çalışmalarında ilk hedef yoğunluk oluşmasını önleyerek, takip edilebilir, kontrol edilebilir alanlar oluşturmaktır. Bu anlamda seçilen tren garları incelendiğinde, A Tren Garı ve çevresi yoğunluk oranı yüksek bir kentsel alanda bulunurken, B Tren Garı ve çevresi yoğunluk oranı nispeten daha az bir alanda bulunmaktadır. Bu nedenle olası sald1rılarda A Tren Garı kent içindeki konumundan kaynaklı kullanıcı sayısının ve araç trafiğinin daha fazla olması nedeniyle, B Tren Garına göre daha yu- 
muşak hedef niteliğinde olacaktır. Ayrıca etraflarındaki üçüncü tarafların etkilenerek zarar görme riskleri A Tren Garı'nda daha yüksek mertebelerde gözlemlenmektedir. Bunlar doğrultusunda kent içindeki konumu kapsamında B Tren Garı, çevresinin daha güvenli ve emniyetli olmasından dolayı, A Tren Garı'na göre daha yüksek olarak puanlandırılmıştır.

\section{Kamu Yollarına Mesafe}

Kentlerde meydana gelen bombalı saldırıların çoğunda hareketli araçlar kullanılmaktadır (Öğünç, 2019). Bu saldırılar çoğunlukla yapılara yönelik saldırılar olup, yolların denetiminin mümkün olmaması araç yoluna mesafenin göz önüne alınmasını gerektirmektedir. Patlama noktası ile hedeflenen yapı arasındaki mesafe, patlama etkisi hesaplarında da kullanılıp, fazla olması patlayıcı maddenin etkilerini hafifleten en önemli faktördür. Bu mesafenin arttırılması patlama etkilerini büyük ölçüde azaltarak yapıyı güvenli hale getirmek için önemli kaynak sağlayacaktır. Emniyet Genel Müdürlügü̈'nün verilerine göre bu mesafe 25 metre olarak asgaride güvenlik sınırında kabul edilmektedir (EGM, 2019). Bu anlamda seçilen tren garları incelendiğinde, B Tren Garı, bina arsasının büyük olması sebebiyle yollardan uzak, yeterli uzaklığı sağladığı görülmüştür. A Tren Garı ise, yola ana cephesini vermektedir. Kamu yollarına olan mesafesinin az olması nedeniyle, B Tren Garı daha güvenli ve emniyetli olarak değerlendirilmiş, A Tren Garı ise kamu yollarına mesafe değerlendirmelerinde daha düşük olarak değerlendirilmiştir.

\section{Arsa Çeperindeki Park Alanları}

Arsa çeperlerindeki park alanları, indi-bindi eylemi yapacak izlenimi verilerek yapılan eylemler nedeniyle korunmasız alanlardır. Bu alanlara yaklaşıp yapıya çarparak veya bu alanlarda araçların kendisini patlatması sonucu yapıya ve çevresine büyük zararlar verilmektedir (Özçelik, 2016). $\mathrm{Bu}$ alanlarda park etmeyi sınırlamak veya kısitlamak, tehditleri alandan uzak tutmaya yardımcı olabilmektedir (Singapore Ministry of Home Affair, 2018). Bu bağlamda tren garları incelendiğinde, A Tren Garı'nın çeperindeki park alanlarına indi-bindi nedeniyle tüm araçların park yapabiliyor olması araç bomba saldırı riskini arttırmaktadır. B Tren Garında ise yalnızca izinli araçlar bu alanlara park yapabilmektedir. Bu da B Tren Garı ve çevresinde araç kontrolünü sağlamak açısından olumlu bir özelliktir. A Tren Garı ve çevresinde, araç kontrolünün sağlanamamış olmaması onu 
diğer gar yapısı ve çevresine göre daha az güvenli ve emniyetli olacak şekilde değerlendirilmesine neden olmuş ve diğer tren garı ve çevresine göre tehditlerden daha fazla etkilenebilir şeklinde değerlendirilmiştir.

\section{Çevre Güvenlik Duvarı}

Yapı ve çevresinin tehditlerden korunması, ayrıca saldırganlara karşı caydırıcı özelliği olması nedeniyle çevre güvenlik duvarları büyük öneme sahiptir. Örnekler güvenlik duvarı uygulaması açısından değerlendirildiğinde, kent içinde konumlanan tren garlarında çevre güvenlik duvarı varlığına rastlanmamıştır. B Tren Garı, yalnızca geniş peyzaj alanı ile arsasını çevreden ayırmış olsa da hiçbir önlem almayan A Tren Garına göre korunma bakımında daha iyi bir tasarım ortaya koymuştur.

\section{Araç Kontrol Noktaları}

Vaziyet yerleşimleri, yapının nasıl kullanılacağına ilişkin analize dayalı olarak, ulaşım gereksinimleri ile başlar. Bunun için gerekli erişim noktalarının sayısı ve türü, araç yaklaşımı ve kullanacakları ulaşım metotları incelenir. Bu süreç çalışma kapsamında değerlendirildiğinde araç erişimi için giriş kontrol noktasının yeri; şüpheli araçların kontrol edilmesi, taranması ve engellenmesi bakımından parsel güvenliğinde önemle üstünde durulması gereken bir karardır. Giriş kontrol noktaları için tasarım yapılırken, mümkünse, giriş noktası bina veya tesisin kendisinden uzak bir yerde olmasına dikkat edilmelidir. Erişim yolları, sürücüleri düşük hızda yaklaşmaya zorlayacak şekilde tasarlanmalıdır. Giriş kontrol noktası, yaklaşan araçların yeterli görsel değerlendirmesini sağlayacak şekilde konumlandırılmalıdır. Güvenlik kontrolünden erişime izin verilmeyen araçlara, beklemek zorunda kalmadan çıkmak için bir yol sağlanmalıdır. Tren garları araç kontrol noktası açısından değerlendirildiğinde, B Tren Garı'nın, araçları ana yoldan ayırarak farklı bir yoldan alıp, kontrolü park alanının girişinde ancak belirli bir görüş mesafesi oluşturarak planlamaktadır. A Tren Garında ise park alanının girişindeki araç kontrol noktası, direkt hızlı akışa sahip ana arter yol üzerinden almaktadır. Bu durum risklerin tespitinin yapılabilmesi açısından etkili değildir.

\section{Parsel İçi Güvenlik Önlemleri}

Kamuya açık alanlarda, olası bombalı saldırılarına karşı koruyucu unsur olarak en yaygin kullanilan elemanlar bariyerlerdir. Bariyerler, yapılardaki bombalı saldırıların etkisinin azaltılması, araç bomba saldırılarının 
yapılara verdiği zararların en aza indirilmesi için tasarlanmış elemanlardır. Bariyerler, bu özellikleri ile kamuya açık alanlar ile yapılar arasında koruyucu katman özelliği göstermekte ve bu işlevi gerçekleştirirken halk tarafından tedirginliğe neden olmamaktadır. (Gebbeken, Warnstedt ve Rüdiger, 2018). Alan çalışmasındaki tren garları parsel içi güvenlik önlemleri kapsamında değerlendirildiğinde ise her ikisinde de erişimi engelleyen; peyzaj, kent mobilyası uygulamasının kullanıldığı görülmüştür. Birbirlerine göre herhangi bir üstünlük sağlamayan bu uygulama, bombalı saldırı gerçekleştiği durumlarda yayılan enerjiyi sönümleyebilmektedir.

\section{Bina Yerleşimi/Yönlenme}

Yapının bulunduğu alan ile ilişkisini tanımlayan yönlenme kriteri, mimari tasarım sürecinin başlangıcıdır. Çalışma kapsamında patlama esaslı saldırı olabilecek ya da oluşturulabilecek alanları riskten korunmak için en önemli kriterlerden biri olmuştur. Cephenin kontrolsüz bir park alanına, caddeye, bitişik yapılara veya gözlemlenmesi zor olan başka bir parsele yönelik sergileyeceği tavır, olası durumlar için risk oluşturmakta ve etkilenme düzeyini arttırmaktadır. Tren garları bina yerleşimi/yönlenmesi kapsamında değerlendirildiğinde, A Tren Garının çevresinde risk oluşturan ana arterlere doğru daha fazla yüzey sunduğu görülmüştür. Bu durum, olası patlamalarda yapının daha fazla etkilenmesine sebep olacaktır. Bu sebeple diğer tren garına göre zayıf olarak değerlendirilmiştir. B Tren Garı ise ana-uzun cephesinin ana yollara bakması ancak daha uzak mesafede bulunması ve arka cephesinin ana yollara dar bir yüzey oluşturmasından dolayı daha olumlu etki ettiği görülmektedir.

\section{Açık Otopark Konumu}

Açık otoparkların yer seçiminde, saldırı riski nedeniyle bina sınırından kaçınılmalıdır. Yapılamıyor ise, park yeri kontrolden geçirilmiş, izinli araçlarla sınırlandırılmalıdır. Her durumda, savunmasız bir öğe olan açık otopark ve bina arasındaki mesafeyi korumak için sönümleyici bir mesafe bırakılması, mesafe az ise bu alanın patlama yüklerinin binaya ulaşımını engelleyecek donanımı arttırılmalıdır. Yapılar incelendiğinde B Tren Garı bina arsası fazla olmasına rağmen kullanıcılar için açık otopark yapı sınırına kadar dayandığı için olumsuz olarak değerlendirilmiştir. Bu durum olası patlamalarda büyük hasarlara ortam hazırlamaktadır. A Tren Ga- 
rında ise yeterli mesafe korunmamış olsa da diğer yapıya göre açı otopark yapı sınırına yaklaştırılmamış, sağlanan mesafe ile daha olumlu bir tutum sergilemiştir.

\section{Diğer Riskli Yapılara Erişim}

Yerleşkesinde birden fazla yapı bulunan alanlarda, yerleşke vaziyet planlarına göre her yapı ve her bir yapının diğer yapılar ile mesafesi etkilenme ve yansıma dalgaları için önemlidir. Eğer ki bu binalarda kullanım amacı olarak farklılaşma var ise bu risk faktörünü yükseltmektedir. Bu bağlamda tren garları incelendiğinde B Tren Garı yarı kentsel alanda bulunuyor olması nedeniyle A Tren Garına göre daha iyi performans sergilemiştir. A Tren Garı kentsel, yoğun bir alanda bulunduğu için risk artmakta, bu da tren garı üzerinde olumsuz etki yaratmıştır.

\section{Tartışma ve Sonuç}

Ülkemizde ve dünyada, çoğunluğu saldırı orijinli olmakla birlikte, bir kısmı kaza sonucu meydana gelen olan pek çok patlama gerçekleşmektedir. Patlamaların ne zaman ve ne şiddette olacağ tahmin edilemediği için kentlerin potansiyel patlama olaylarına karşı korunmasına yönelik güvenlik önlemlerinin alınması gerekmektedir. Bu güvenlik önlemleri kent dokusunun önemli ögelerinden olan yapıların mimari ve yapısal tasarımı s1rasında alınabilecekken, mevcut yapılara entegre de edilebilmektedir. Bu bağlamda, olası risklerin azaltılması için yapıların patlama yüklerine karşı dayanıklı bir şekilde tasarlanmasında, yapılı çevrenin oluşturulmasında etkin aktörler olan mimar, mühendis ve şehir planclarına büyük rol düşmektedir. Yapılan çalışmada, kent içi bombalı saldırılara karşı alınabilecek önlemler farklı ülkelerin bu konuda geliştirmiş oldukları standartlar ve akademik çalışmalar incelenerek kent-yapı ilişkisi bağlamında değerlendirilmiştir. Sonrasında söz konusu önlemlerin hangi mertebelerde ve ne tür bombalı saldırılara yönelik olacağına dair çalışmaya sınırlandırmalar getirilmiştir. Öncelikle araç bomba saldırılar odak noktası alınarak, bunun dışında kalan ve kimyasal yollar ile yaralayan veya hasar veren saldırılar çalışmanın dışında tutulmuştur. Ayrıca; bina özelindeki biçimlenme, mimari tasarım ve malzeme kararları kapsamında önlemler de çalışma kapsamı dışında tutularak, sadece kent ile ilişki kurulan çevre düzenlemeleri ele alınmıştır. 
Çalışmanın ilk aşamasında kent dokusu içerisinde yapıların bombalı saldırılara karşı tasarım için farklı ülkelerin geliştirmiş oldukları standartlara ve akademik çalı̧̧malara dayalı literatür incelenmiştir. Farklı ülkelerde geliştirilmiş olan patlama yüklerine karşı kent dokusu içerisinde tasarım standart ve kılavuzları karşılaştırmalı olarak değerlendirilmiştir. Bu karşılaştırmalar sonucunda kent içi bombalı saldırılara karşı yapı çevresi ve kent dokusuna yönelik kriterler elde edilmiştir. Çevresel tasarım süreçlerinde bir arada olması gereken bu kriterlerin beraber değerlendirilmesi bir problem özelliği taşımaktadır. Bu problem özelliğine yönelik ise ÇKKV metodolojisinden AHP yöntemi kullanılarak kriterler arasında hiyerarşik bir sıralama elde edilmiştir. Kriter ağırlıklarının hesaplanması ile patlama yüklerine karşı tasarımda hangi kriterlerin daha büyük öneme sahip olduğuna ulaşılmıştır. Bu noktada kriter ağırlıklarına bakıldığında, ana başlıklar bakımından yapı parselinin düzenlenmesi en önemli koruma katmanı olarak görülmüştür. Yapı ile kenti bağlayan, yapı çevresindeki dış boşluğu ifade eden yapı parseli bombalı saldırılarda büyük yıkımlara neden olabileceği gibi alınacak önlemlerle de riski azaltmaktadır. Tasarım elemanı olan alt parametreler bağlamında ise araç bomba saldırılara yönelik en önemli kriter diğer ana başlıktaki kamu yollarına mesafe olarak bulunmuştur.

Sonraki aşamada, kriter ağırlıkları göz önünde bulundurularak yüksek hızlı tren garı yapıları gözleme dayalı tespit metodu ile değerlendirilmiştir. Yapı parseli düzenlemesi açısından, A Tren Garının konumu, aynı fonksiyondaki diğer yapıya göre kente daha yakın olduğu için güvenlik seviyesi olumsuz etkilenmiştir. Kente yakınlık hem kullanıc sayısını hem olası bombalı saldırılardan etkilenecek çevresel faktörlerin sayısını arttırmıştır. Bunlara ek, arsa çevresinde kontrolsüz park alanlarının oluşmasına da sebep olmuştur. Park alanlarının tasarım sırasında belirlenmesi ve özellikle potansiyel risk taşıyan arsa çeperine park yasağı getirilmesi araçların kontrolsüz hareketinin önüne geçecek ve korumaya destek sağlayacaktır. Çevre ile olan ilişki açısından değerlendirildiğinde ise A Tren Garı ve çevresi için mevcut yapılara yönelik değiştirilmesi zor olan parametrelerin olduğu görülmektedir. Ancak yapının kent içindeki konumunun, araç yollarına mesafesinin değiştirilemez olmasına rağmen, çevre ile kuracağı ilişkinin sınırlandırılması risklerin önüne geçecektir. Karşılaştırmalar sonucunda ise B Tren Garı, kentsel tasarım alanında bulunması ve bölgesel olarak bir planlamaya tabi tutulması nedeniyle çevre ile ilişki ve yapı parsel düzenlemesi bağlamında daha az risk teşkil etmektedir. A Tren garı 
ise çevre ile ilişki bağlamında fiziksel kayıp etkisine müdahale edilemeyeceğinden daha riskli bulunmuş ve koruma önlemleri ile iyileştirilerek güvenlik açıkları kapatılması öngörülmüştür. Ancak önlem amaçlı sonradan yapılacak müdahalelerin kullanıcılar üstünde tedirginlik oluşturmamasina özen gösterilmelidir.

Tüm kriterler bakımından yüksek hızlı tren garlarının performansları karşılaştırıldığında ise, AHP anketinde en önemli parametre olarak karşımıza çıkan "Kamu Yollarına Mesafe" nde tren garlarının ortalama olarak en iyi performansı sergiledikleri parametre olduğu görülmüştür. Kamu Yollarına Mesafe açısından tren garlarının performanslarının değerlendirme sonucunda istenilen gibi olması, tasarımcı ekibinin bu konudaki hassasiyetinin bulunduğunu göstermesi açısından önemlidir. Tasarım elemanlarına ilişkin önem derecelerinde dördüncü sırada bulunan "Çevre Güvenlik Duvarı" ise tren garları değerlendirmesinde en kötü performans sergiledikleri parametreler arasında olduğu görülmüştür. Tren garları kentsel alanda bulunmaları ve içerisinde birçok sosyo-kültürel unsur barındırması nedeniyle çevre güvenlik duvarı gibi herhangi bir sınırlandırma getirilememiştir. Bu nedenle de tren garlarında çevre güvenlik duvarının olmaması tren garlarında bir güvenlik zafiyeti oluşturmuştur. Ancak bu güvenlik zafiyetinin önüne geçilmesi "Parsel İçi Güvenlik Önlemleri" kapsamındaki çeşitli tasarım elemanlarınca (bariyerler, peyzaj elemanları...vs) ile sağlanmalıdır.

Yapılan çalışma ile dünyada her dönemde önemli risk teşkil eden, büyük kayıplara yol açan kent içi bombalı saldırılarda yapılara yönelik tehdit unsurlarının nasıl azaltılabileceği kente dair tasarım kararları merceğinde incelenmiştir. Böylece mimarlar, şehir ve bölge planlamacılar, yetkili kurumlardaki personeller gibi kentlerin şekillenmesinde görev alanların dikkatini bu konuya çekmek, güvenlik konusuna yeni bir bakış açısı kazandırmak ve farkındalık düzeylerini arttırmak amaçlanmıştır. Son söz olarak, bilinçli toplum ve güvenli kentleşmenin temellerinin atılmasına yönelik önem teşkil eden bu çalışma, sonraki çalışmalar için daha kapsamlı oluşturulması hedeflenen değerlendirme modelleri ile farklı fonksiyondaki yapıların bombalı saldırılardaki risk düzeyleri ile mimarlık ilişkisinin ortaya konulmasını, tasarım kaynaklı zayıflıkların tartışılmasını ve yapılacak daha detaylı çalışmalara yön verilmesini sağlayacaktır. 


\section{Extended Abstract}

\section{Evaluation of Measures in Urban Areas for Vehicle Bomb Attacks in The Context of City-Building Relation with AHP Method}

\author{
Berru İzel Gökgöz \\ ORCID: 0000-0002-0096-1595
}

\author{
Zeynep Yeşim İlerisoy \\ ORCID: 0000-0003-1903-9119
}

Due to the increasing global terrorism in the world after 1980, it has been occurred many bomb attacks of different scales. These attacks are man-made disasters that affect the whole country, especially buildings or region in which they happened. Even though the types and intensity of these attacks change periodically, there are serious material and moral losses as a result of such actions. Referring to Turkey's recent history of the last ten years, these bitter attacks have been carried out in the city center and are in the nature of examples confirming the vulnerability. In order to close this security gap and ensure the safety of life, it is crucial to take measures against city and building scale bomb attacks. However, in order to take these precautions, it is necessary to analyze how these attacks affect their environment.

The magnitude of the damage caused by the explosion on structures depends on different variables. To list these effects; (i) The location of the explosion, (ii) The type and quantity (weight) of the explosive, (iii) The distance between the explosion center and the structure, (iv) The design characteristics of the structures to be affected become prominent. The location of the explosion, the type and amount of explosive are variables that cannot be intervened in advance. However, by intervening in the distance between the center of the explosion and the structure and also the design characteristics of the structures to be affected, the damage to be experienced can be reduced. 
Within the scope of the measures to be taken, there are many criteria that affect design stage decisions related to urban development, architectural design, building parcel and building formation. In addition to this, the diversity of bomb attacks dealt with, such as individual suicide attacks, package bomb attacks, vehicle bomb attacks, are also important variables for the measures to be taken. Some limitations have been imposed on this study at the aforementioned points. The effects of design decisions regarding the building and its surroundings on the protection process against bomb attacks in cities are revealed and the forming and design decisions for buildings are excluded. In line with these limitations, the criteria and parameters that directly affect the structure and its surrounding against vehicle bomb attacks were analyzed and included in the scope of the research.

First of all, the decision problem, which is important to constitute the hierarchical structure in the method, was determined as "environmental design against vehicle bomb attacks in urban areas". Two main headings (relationship with the environment, arrangement of the building parcel) were created through the literature review, expert opinions and 9 parameters were determined under these main headings. The relationship with the environment includes areas (roads, sidewalks, neighboring parcels, neighboring blocks) that are difficult to control or even uncontrollable against structures standing outside the building block. Through the measures to be taken under this subject, it is aimed to increase the protection of the target structure by reducing the risks of the environment on the building parcel. The arrangement of the building parcel covers the area between the parcel boundary and the building. It reduces the probability of target selection by reducing weak points, makes it easier to identify the action to be planned and becomes a deterrent shield. After the parameters were determined, general weights for the main headings and sub-parameters were obtained by using the Analytical Hierarchy Process (AHP) method from the Multi-Criteria Decision Making (MCDM) methodology. The resulting ranking were listed as; Distance to Public Roads, Location in the City, Vehicle Parks on the Perimeter of the Parcel, Perimeter wall, Building Layout \& Direction, Vehicle Control Points, Open Parking Lot, Security Measures and Access to Other Risky Buildings. Finally, in the case study, among the transportation buildings that are important at the city scale, high-speed train stations were selected. A comparison of the selected train stations according to their security levels against vehicle bomb attacks was conducted. Because of the safety concerns, these structures were named as Train Station- $A$ and Train Station-B in the whole study. 
In terms of building parcel arrangement, the security level was negatively affected as the location of Train Station A is closer to the city center than the other building with the same function. Proximity to the city has increased both the number of users and environmental factors that will be affected by possible bomb attacks. In addition to these, it also caused the formation of uncontrolled parking areas around the land. The determination of the parking areas during the design phase and the imposition of a parking ban especially on the perimeter of the parcel having potential risks will prevent the uncontrolled movement of vehicles and increase the protection level. When it is evaluated in terms of the relationship with the environment aspect, it is seen that there are parameters for the Train Station A and its surroundings which are difficult to change for the existing structures. However, although the location of the building in the city and its distance to the roadways cannot be changed, limiting the relationship with the environment will prevent the risks. As a result of the comparison between these 2 structures, Train Station B poses less risk in terms of its relation with the environment and building parcel arrangement due to its location in the urban design area and being a result of a regional planning concept. Train station A, on the other hand, was found to be more risky as the physical loss effect could not be intervened in the context of its relationship with the environment and it was envisaged to close security gaps by improving with protection measures. However, care should be taken to ensure that subsequent interventions for precautionary purposes do not cause anxiety for its users.

As a result, with this study, it is aimed to draw attention of those involved in shaping cities such as architects, city and regional planners, personnel in authorized institutions, to gain a new perspective on security issues and to increase their level of awareness. For following studies, it is also aimed to reveal the relationship between architecture and risk levels of buildings with different functions in bomb attacks with the evaluation models to be developed more comprehensively. Thus, it is considered that the foundations of conscious society and safe urbanization can be laid more solidly.

\section{Kaynakça/References}

Booth, A., Welch, S. ve Johnson, D. R. (1976). Crowding and urban crime rates. Urban Affairs Quarterly, 11(3), 291-308. doi:10.1177/107808747601100301

Bureau of Indian Standards [BIS]. (1969). IS 4991 (1968): Criteria for blast resistant design of structures for explosions above ground. 
Coaffee, J., Moore, C., Fletcher, D. ve Bosher, L. (2008). Resilient design for community safety and terror-resistant cities. Proceedings of the Institution of Civil EngineersMunicipal Engineer, 161(2), 103-110. doi:10.1680/muen.2008.161.2.103

EGM. (2019). Patlatma kaynaklı etki hesap yöntemleri tasarım ve güçlendirme ilkeleri. Emniyet Genel Müdürlüğü İnşaat Emlak Dairesi Başkanlığı.

Ergil, D. (1992). Uluslararası terörizm. Ankara Üniversitesi Siyasal Bilgiler Fakültesi Dergisi, 47(3), 139-143.

Eskew, E. ve Jang, S. (2012). Impacts and analysis for buildings under terrorist attacks, 37.

Federal Emergency Management Agency (FEMA). (2003a). FEMA 427. Primer for design of commercial buildings to mitigate terrorist attacks. Washington, D.C.: DHS.

Federal Emergency Management Agency (FEMA). (2003b). FEMA 426. Reference manual to mitigate potential terrorist attacks against buildings. U.S. Deparment of Homeland Security.

Federal Emergency Management Agency (FEMA). (2003c). FEMA 428. Primer to design safe school projects in case of terrorist attacks. Washington, D.C.: DHS.

Federal Emergency Management Agency (FEMA). (2007). FEMA 430. Site and urban design for security guidance against potential terrorist attacks. Washington, D.C.: DHS.

Federal Emergency Management Agency (FEMA). (2011). FEMA 426 BIPS 06. Reference manual to mitigate potential terrorist attacks against buildings. U.S. Department of Homeland Security. https://www.wbdg.org/FFC/DHS/bips_06.pdf adresinden erişildi.

Gebbeken, N. ve Döge, T. (2010). Explosion protection-architectural design, urban planning and landscape planning. International Journal of Protective Structures, 1(1), 1-21. doi:10.1260/2041-4196.1.1.1

Gebbeken, N., Warnstedt, P. ve Rüdiger, L. (2018). Blast protection in urban areas using protective plants. International Journal of Protective Structures, 9(2), 226-247. doi:10.1177/2041419617746007

Gençtürk, T. (2012). Terör kavramı ve uluslararası terörizme farklı yaklaşımlar. Başkent Universitesi Stratejik Araştırmalar Merkezi, 11.

General Services Administration (GSA). (2013). Alternate path analysis \& design guidelines for progressive collapse resistance. http:// www.gsa.gov/portal/content/103205 adresinden erişildi.

Glaeser, E. L. ve Shapiro, J. M. (2002). Cities and warfare: the impact of terrorism on urban form. Journal of Urban Economics, 51(2), 205-224.

doi:10.1006/juec.2001.2262

Gökgöz, B. İ., İlerïsoy, Z. Y. ve Soyluk, A. (2020). Acil durum toplanma alanlarının ahp yöntemi ile değerlendirilmesi. Avrupa Bilim ve Teknoloji Dergisi, (19), 935-945. doi:10.31590/ejosat.739544

Hürriyet. (2014). 13 Aralık 2020 tarihinde Hürriyet: https:/www.hurriyet.com.tr/gundem/reyhanli-saniklari-hakim-karsisinda-25775623 adresinden erişildi. 
Intelligence and Security Committee. (2006). Report into the London terrorist attacks on 7 July 2005. https://assets.publishing.service.gov.uk/government/uploads/system/uploads/attachment_data/file/224690/isc_terrorist_attacks_7july_report.pdf adresinden erişildi.

Kang, K.-Y. ve Lee, K.-H. (2014). Vulnerability assessment model for cost efficient antiterrorism design of super high-rise buildings. Journal of Asian Architecture and Building Engineering, 13(2), 413-420. doi:10.3130/jaabe.13.413

Kang, K.-Y., Park, S.-Y., Heo, H., Lee, M.-S. ve Lee, K.-H. (2019). Development of the vulnerability assessment model of explosive terrorism in multi-use buildings. Journal of Asian Architecture and Building Engineering, 18(3), 170-179. doi:10.1080/13467581.2019.1614452

Karlos, V., Larcher, M. ve Solomos, G. (2018). Review on soft target/public space protection guidance. Joint Research Centre. doi:10.2760/553545

Lew, I. P. (2012). Planning ahead is critical to mitigating the potential of vehicle bombs., 5 .

NaCTSO. (2006). Counter terrorism protective security advice for shopping centres. London: NaCTSO. https://assets.publishing.service.gov.uk/government/uploads/system/uploads/attachment_data/file/375143/Shopping_Centres_Reviewed.pdf adresinden erişildi.

NaCTSO. (2008a). Counter terrorism protective security advice for commercial centres. London: NaCTSO.

NaCTSO. (2008b). Counter terrorism protective security advice for hotels and restaurants. London: NaCTSO.

NaCTSO. (2012). Protecting crowded places: design and technical issues. United Kingdom: London: NaCTSO.

NaCTSO. (2014). Counter terrorism protective security advice for general aviationrevised 2014. London: NaCTSO. https://assets.publishing.service.gov.uk/government/uploads/system/uploads/attachment_data/file/374665/aviation-security-reviewed.pdf adresinden erişildi.

National Academies of Sciences, Engineering, and Medicine (NAS) (2018). Reducing the threat of improvised explosive device attacks by restricting access to explosive precursor chemicals. https://www.nap.edu/resource/5966/031577\%20Key\%20Recommendations\%20Reducing\%20Threat\%20IED\%20Attacks.pdf adresinden erişildi.

Öğünç, G. İ. (2019). Kent güvenliğinde araç bomba saldirisi tehdidi. Assam Uluslararasi Hakemli Dergi 13. Uluslararasi Kamu Yönetimi Sempozyumu Bildirileri Özel Sayısı, 18.

Özçelik, N. (2016). Pkk ve bombalı araç saldırıları. SETA, (170), 24.

Saaty, T. L. ve Kearns, K. P. (1985). Analytical planning: The organization of systems. International series in modern applied mathematics and computer science (1st ed.). Oxford; New York: Pergamon Press.

Singapore Ministry of Home Affair. (2018). Guidelines for enhancing building security in Singapore. Security in Singapore. Singapore: Ministry of Home Affairs. 
Smilowitz, R. (2016, 14 Eylül). Designing buildings to resist explosive threats I WBDG - Whole Building Design Guide. 28 Nisan 2020 tarihinde https://www.wbdg.org/resources/designing-buildings-resist-explosive-threats adresinden erişildi.

US Department of Defense. (2005). Ufc 3-340-02 structures to resist the effects of accidental explosions. Washington DC. https://www.wbdg.org/FFC/DOD/UFC/ARCHIVES/ufc_3_340_02.pdf adresinden erişildi.

US Department of Defense. (2007). Ufc 4-010-01 dod minimum antiterrorism standards for buildings. Washington DC. https:/www.hsdl.org/?view\&did=477613 adresinden erişildi.

Yenimeram. (2015). 09 Temmuz 2020 tarihinde Yenimeram: https://www.yenimeram.com.tr/dunyadan-saldiriya-kinama-ve-tepkiler150032.htm adresinden erişildi. 